\title{
RESEARCH PAPER \\ Assessing long- and short-term trends in cereal yields: the case of Chile between 1929 and 2009
}

\author{
Alejandra Engler, and Alejandro del Pozo \\ Facultad de Ciencias Agrarias, Universidad de Talca, Casilla 747, Talca, Chile.
}

\begin{abstract}
A. Engler, and A. del Pozo. 2013. Assessing long- and short-term trends in cereal yields: the case of Chile between 1929 and 2009. Cien. Inv. Agr. 40(1):55-67. Cereal grain yields have increased worldwide during the $20^{\text {th }}$ century as a consequence of plant breeding, improved cultural practices and intensive use of inputs. However, there is evidence that there are differences in yield pattern evolution across countries and cereals. The purpose of this study was to compare trends in the yields of the most commonly produced cereals in Chile, namely wheat, oat, barley, maize and rice, to identify similarities in trends across crops and to estimate long-term growth rates in the yields and their changes over time. Data for wheat, barley, oat, rice and maize yields between 1929 and 2009 were obtained from the Chilean Oficina de Estudios y Políticas Agrarias (ODEPA). A first-order autoregressive (AR1) model with trend was applied to a time series analysis of yield data to estimate the relative rates of yield increase and short-run adjustments to yield progress. There was a break in the time series for wheat, barley and oat in approximately 1980. Following this break, the yields exhibited notable increases, with these three cereals reaching similar yields (4.4-4.7 ton ha ${ }^{-1}$ in the last decade). The long-term relative rate of yield was approximately $0.6-1 \%$ before the break (approximately 1980) and slightly less after the break. Rice yields decreased from the thirties to the sixties and have increased since then. The maize yield was very low before the sixties $\left(<2 \mathrm{t} \mathrm{ha}^{-1}\right)$ but has since increased steadily, reaching an average of $10.8 \mathrm{tha}^{-1}$ in the last decade. Economic and agronomic changes that have taken place in the country explain the break observed in the cereal yield trends.
\end{abstract}

Key words: Barley, oat, maize, rice, wheat, yield progress.

\section{Introduction}

Significant technological progress in agriculture made in the last century contributed to major increases in productivity. In particular, yield growth can be explained by two types of technological

Received July 17, 2012. Accepted January 20, 2013. Corresponding author: adelpozo@utalca.cl improvement. The first is plant breeding, which has made a consistent contribution to yield increases since the 1930s (Crow, 1998; Elgi, 2008). A large number of modern or high-yielding varieties of wheat, maize, rice and other cereals have been released since 1960 in different parts of the world, including Latin America and in Chile in particular, as a consequence of the Green Revolution (Evenson and Gollin, 2003). The 
second is improved agronomic cultural practices and inputs (Evans, 1993; Duvick, 2005), which can be considered a complement to plant breeding and has involved new fertilization practices and the use of increasing amounts of fertilizers (Evans, 1993) and chemical control of weeds (Milberg and Hallgren, 2004), insects and fungi (Evans, 1993). However, environmental conditions are also relevant in explaining yield, with climate change being a leading issue in our day. According to Lobell and Field (2007), the warmer temperatures observed in recent years have had negative impacts on yields, although this has been offset by increased use of fertilizers and agrochemicals.

Worldwide, various crops have experienced major increases in yields during the $20^{\text {th }}$ century (Egli, 2008). The yield progress of wheat in 21 countries indicate, in general, low yield gains in the first half of the century, followed by explosive growth in the second half of the century (Calderini and Slafer, 1998; Latiri et al., 2010). Yields of other crops, such as maize (Crow, 1998; Duvick, 2005; Egli, 2008), rice in the Philippines (IRRI) and Japan (Fischer and Edmeades, 2010), potato in Canada (Grant, 1997) and soybean in the USA (Egli, 2008), have exhibited similar trends.

Nevertheless, important differences in yield growth rate and in the timing of changes in yield growth have occurred. For example, increases in wheat yields in developed countries such as the UK, Germany and France have been greater and have occurred 10 to 20 years before wheat yield increases in Tunisia or India (Calderini and Slafer, 1998). Additionally, the yield progress of wheat, barley, potato and sugar beet in the Czech Republic over a 75 -year period has been lower than that in Germany (Chloupek et al., 2004).

In Chile, wheat yield experienced a strong increase from 1980 onward, this breakpoint occurring much later in Chile and in Uruguay than in 21 other countries analyzed by Calderini and Slafer (1998). Why did wheat yield in Chile only increase moderately before 1980, despite highly productive cultivars (Mellado, 1999; 2000) having been available before the seventies? Did other cereals produced in Chile, such as barley, oat, rice and maize, have similar yield trends? What factors or events in Chile produced a dramatic change in the wheat yield trend, and presumably in the yield trends of other cereals, after the 1980s?

The availability of improved technology is certainly a necessary condition for increasing productivity; however, the processes of innovation and technology adoption depend not only on the availability of the technology but also on economic and policy incentives and the public (Dadi et al., 2004; Halloran and Archer, 2008). In addition to plant breeding programs, international seed companies releasing new varieties and hybrids, and improved crop management and inputs (fertilizers and herbicides, among others) during the eighties, the Chilean economy underwent major changes, including deregulation and liberalization (Edwards, 1985), which encouraged greater market competitiveness, reduced trade barriers and made imported technology and inputs more affordable for producers. All these factors may have contributed to the rapid increase in productivity in wheat and most likely in other cereals in Chile.

The objectives of this study were a) to analyze the yield trend exhibited by the most commonly produced cereals in Chile, namely, wheat, oat, barley, maize and rice; b) to identify similarities and differences in yield trends across crops; and c) to estimate the long-term growth rates of the yields and their changes over time. To achieve these objectives, we used a time series model to distinguish between short- and long-term trends, which allowed us to better understand the evolution of the yield trends and the process of innovation in productivity.

\section{Material and methods}

Information on annual cereal yields and the planted areas of wheat, barley, oat, rice and maize between 
1929 and 2009 were obtained from the Chilean Oficina de Estudios y Políticas Agrarias (ODEPA). The information was based on data collected by the Instituto Nacional de Estadísticas (INE). Data for 1975 and subsequent years are available on line at www.odepa.cl. Data for years prior to 1975 were obtained directly from ODEPA.

A first-order autoregressive AR(1) model with trend was applied to the time series yield data to estimate the relative rates of yield increases, as well as short-term adjustments to yield progress. The estimated equation is as follows:

$y_{t}=\beta_{0}+\beta_{1} y_{t-l}+\beta_{2}$ time $+e_{t}$

where $y_{t}$ is the natural logarithm of the annual yield of each of the crops considered in the analysis, $\beta_{0}, \beta_{1}$ and $\beta_{2}$ are coefficients to be estimated and $e_{t}$ is the error term. In this model, the coefficient $\beta_{2}$ is the long-term relative rate of yield increase and the coefficient $\beta_{1}$, associated with the $\operatorname{AR}(1)$ component, captures the short-term adjustments (Greene, 2008). Changes in the yield pattern throughout a series could be a consequence of technological, social or economic events or public policies. To check the existence of these changes or breaks, we applied the Chow test to equation 1 for each year of the time series between 1940 and 1990. The Chow test compares the residuals generated by the regression estimation for the full time period to the residuals generated by two regressions derived from dividing the time period into two parts. If the residuals of the regression for the full time period do not differ from the sum of the residuals of the two regressions of the partial periods, it can be assumed that no structural breaks occurred (Lütkepohl, 2005). When the Chow test identified structural changes for a range of years, we narrowed the moment of break using the Akaike information criterion (AIC) and the Schwarz criterion, which are often used as guides for model selection. One break and combinations of two breaks were evaluated using the highest values of the F statistic at different moments in time.
Once we established the existence of a structural break, we used a binary variable to represent the break. This binary variable takes a value of 1 for the year when the break occurs and subsequent years and takes a value of 0 otherwise. It should be noted that more than one break can be expected over the time period considered, and therefore more than one binary variable can be used in each equation. We used the binary variable in a multiplicative form to capture a change in the parameter values $\beta_{1}$ and $\beta_{2}$ as follows:

$$
y_{t}=\beta_{0}+\beta_{1} y_{t-1}+\beta_{2} \text { time }+\beta_{3} D_{T} \cdot y_{t-1}+\beta_{4} D_{T} \cdot \text { time }+e_{t}
$$

where $D_{T}$ is the binary variable for a break at moment $\mathrm{T}$, assuming only one structural break in the equation. According to equation 2, the effect of past yields on current yield will be $\beta_{1}$ for the years prior to $\mathrm{T}$ and $\beta_{1}+\beta_{3}$ for the years after $\mathrm{T}$, and the same is true for the relative growth rate $\beta_{2}$ and $\beta_{2}+\beta_{4}$.

The yield series for each crop was tested to determine if it was trend-stationary using the augmented Dickey-Fuller and Phillips-Perron tests and the partial autocorrelation function, with inconclusive results (Enders, 1995; Greene, 2008). To estimate the parameters of the model, we used ordinary least squares (OLS) estimation, which according to Fuller (1996) is an efficient estimator in autoregressive equations. The estimations were carried out using the Eviews 6.0 statistical package.

\section{Results}

\section{Wheat, barley and oat}

Wheat is the most important crop in Chile in terms of planted area (Table 1) and is cultivated in a wide range of climates, from the semi-arid Mediterranean climate ( $\sim 350 \mathrm{~mm}$ of rain annually) in the north, with and without irrigation, to the humid temperate climate $(2000 \mathrm{~mm}$ of rain annually) in the south. Wheat yields in Chile 
showed moderate increases from 1929 to the eighties and then a strong increase in the next three decades (Figure 1a; Table 1). Barley and oat yields exhibited similar patterns (Figure 1b). The average yields of the three cereals, approximately 4.4-4.7 t ha $^{-1}$ (Table 1), have been similar during the last decade. However, there have been different trends in the three crops in terms of planted area. While there has been a notable reduction of planted area for wheat and barley over time, the planted area for oat has remained relatively unchanged since the thirties (Table 1).

Table 1. Ten-year average of planted area (ha), yield average $\left(\mathrm{t} \mathrm{ha}^{-1}\right)$ and yield growth $\left(\mathrm{kg} \mathrm{ha}^{-1}\right.$ year $\left.{ }^{-1}\right)$ for wheat, maize, barley, oat and rice, from 1929 to 2009.

\begin{tabular}{|c|c|c|c|c|c|c|c|c|c|c|c|c|c|c|c|}
\hline & Wheat & & & Barley & & & Oat & & & Rice & & & Maize & & \\
\hline Period & Area & Yield & $\begin{array}{l}\text { Yield } \\
\text { growth }\end{array}$ & Area & Yield & $\begin{array}{l}\text { Yield } \\
\text { growth }\end{array}$ & Area & Yield & $\begin{array}{l}\text { Yield } \\
\text { growth }\end{array}$ & Area & Yield & $\begin{array}{l}\text { Yield } \\
\text { growth }\end{array}$ & Area & Yield & $\begin{array}{l}\text { Yield } \\
\text { growth }\end{array}$ \\
\hline $1929 / 39$ & 748,866 & 1.1 & -4 & 69,111 & 1.5 & -23 & 98,437 & 1.1 & -26 & 10,786 & 4.0 & - & 45,746 & 1.5 & -17 \\
\hline $1940 / 49$ & 760,907 & 1.2 & 18 & 48,961 & 1.6 & 20 & 84,368 & 0.99 & 3 & 29,876 & 3.4 & -99 & 48,942 & 1.3 & -4 \\
\hline $1950 / 59$ & 785,807 & 1.3 & 23 & 53,317 & 1.6 & 28 & 93,621 & 1.1 & 24 & 30,537 & 2.6 & -17 & 66,040 & 1.8 & 87 \\
\hline $1960 / 69$ & 744,626 & 1.6 & 51 & 45,935 & 2.0 & 45 & 78,285 & 1.3 & 47 & 29,880 & 2.6 & -8 & 82,178 & 2.9 & 164 \\
\hline $1970 / 79$ & 626,161 & 1.6 & 00 & 62,267 & 1.9 & -0.6 & 82,617 & 1.5 & 29 & 29,215 & 3.1 & 30 & 99,900 & 3.3 & -4 \\
\hline $1980 / 89$ & 508,812 & 2.4 & 177 & 32,386 & 2.7 & 175 & 74,153 & 2.1 & 98 & 36,096 & 3.9 & 143 & 112,701 & 6.1 & 477 \\
\hline $1990 / 99$ & 395,487 & 3.6 & 80 & 25,200 & 3.5 & -0.5 & 75,955 & 2.9 & 13 & 27,982 & 4.4 & 46 & 94,933 & 8.9 & 102 \\
\hline $2000 / 09$ & 350,852 & 4.6 & 120 & 18,928 & 4.7 & 107 & 95,516 & 4.4 & 81 & 25,360 & 5.0 & -20 & 117,625 & 10.8 & 117 \\
\hline
\end{tabular}

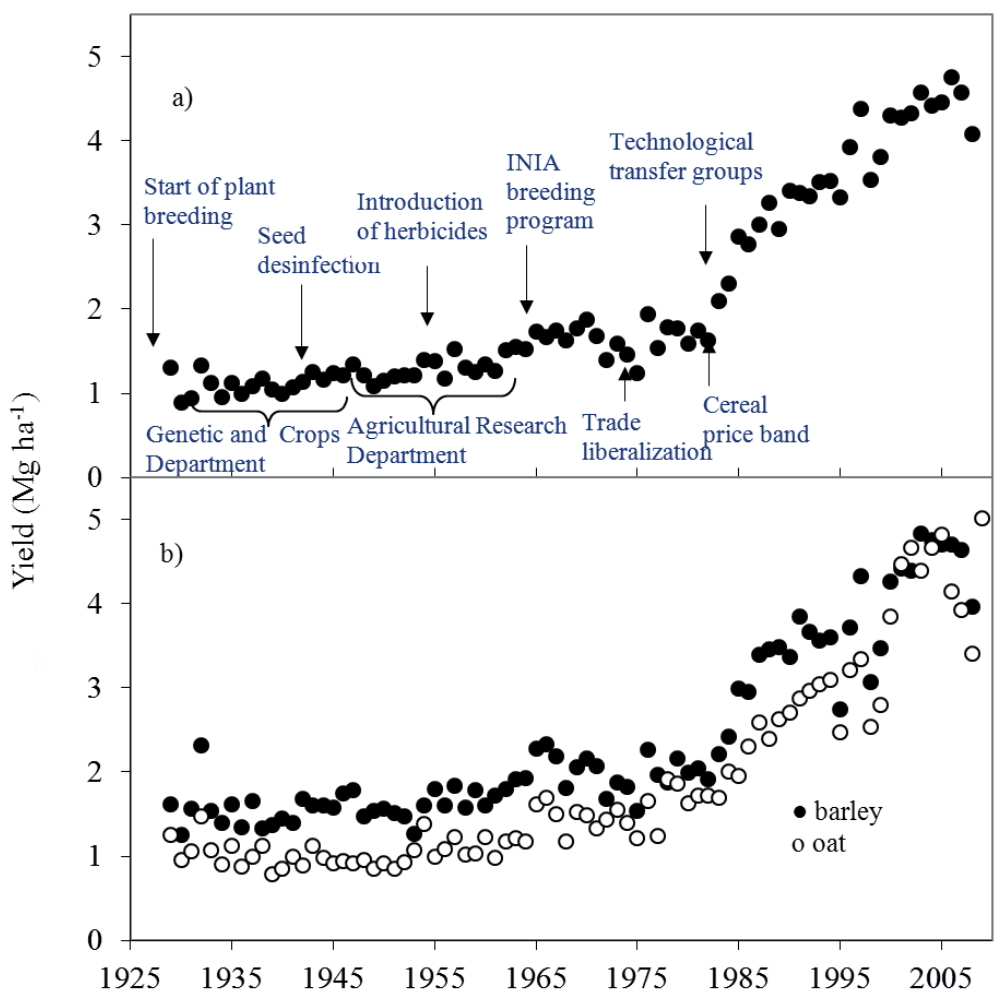

Figure 1. Average grain yield of small-grain cereals in Chile from 1927 to 2009. Specific events are marked with arrows for wheat (a) and are similar for barley and oat (b). 
The Chow test revealed multiple years of breaks for these three cereals. Therefore, the years with higher probabilities of change were evaluated with the AIC and the Schwarz criterion (Figure 2). The years selected were 1962, 1972 and 1983 and the corresponding preceding and subsequent years. The best fits for wheat, barley and oat were obtained by considering only one structural break in 1983 (wheat) and 1984 (barley and oat).

Using the most likely break year, we estimated the model for each cereal yield. In all the equations, the traditional assumptions for linear regression models were satisfied (Greene, 2008). The goodness of fit of the AR(1) model was greater than $90 \%$, indicating that the data set was well represented (Table 2$)$. The long-term relative rates of yield $\left(\beta_{2}\right.$ in equation 1) before the break year were $1,0.8$, and $0.6 \%$ for wheat, oat and barley, respectively. After that year, the relative rates decreased slightly in all three cases $\left(0.04-0.06 \%, \beta_{4}\right.$ in Table 2). However, the yield growth of wheat, calculated for each decade, increased after the 1980s from an average of $18 \mathrm{~kg} \mathrm{ha}^{-1}$ year $^{-1}$ (for the period 1929-1979) to $126 \mathrm{~kg} \mathrm{ha}^{-1}$ year $^{-1}$ (for the period
1980-2009) (Table 1). Similar trends were detected for barley and oat (Table 1).

Rice

Commercial production of rice in Chile began in 1937, after trials conducted in the twenties. Rice has been cultivated exclusively in the central valley, in a Mediterranean type of climate and under flooded conditions. The yield progress of rice in Chile displays a totally different pattern from the yield progress of the other three smallgrain cereals (Figure 3a). The ten-year averages indicate decreases in rice yield from the thirties to the sixties, followed by increases from the seventies to the nineties (Table 1). Consequently, the yield growth of rice was negative from the thirties to the sixties and then positive through the nineties. A decreasing trend has occurred in the past decade, influenced by declines in yields between 2001 and 2004 and a substantial decrease in 2009 (Table 1). The planted area was lower in the thirties, but after that it remained steady until this past decade, during which it decreased slightly (Table 1).

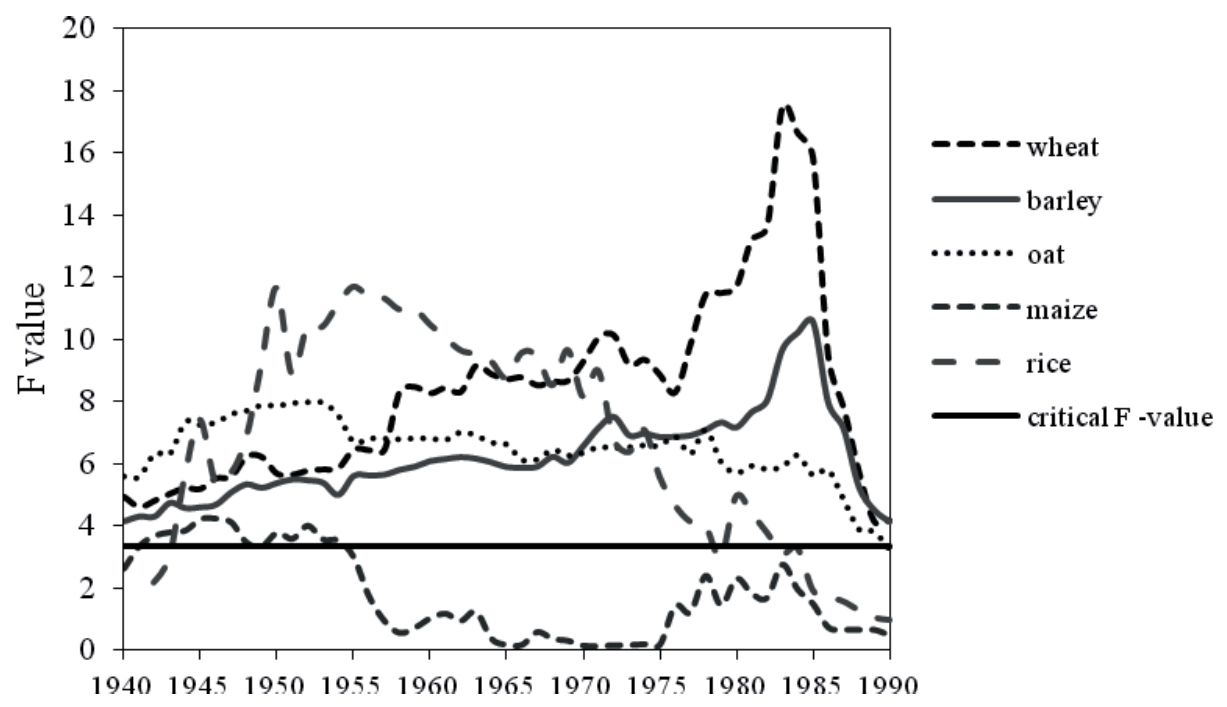

Figure 2. Estimated and critical F-values using the Chow test to identify structural breaks in AR(1) models with trends for wheat, oat, barley, maize and rice. 
Table 2. Estimation results from the first-order autoregressive models with trends for wheat, maize, barely and oat yields.

\begin{tabular}{|c|c|}
\hline Cereal & Estimated equation / t-value in brackets / $\mathrm{R}^{2}$ \\
\hline (a)Wheat & $\begin{aligned} y_{t}= & -18.4+0.04 y_{t-1}+0.01 \text { time }+0.49 D_{83} \cdot y_{t-1}+-0.0006 D_{83} \cdot t i m e+e_{t} \\
& (-6.8)(0.4)\end{aligned}$ \\
\hline (b)Barley & $\begin{array}{l}y_{t}=-\begin{array}{ll}10.1+0.15 \\
(-4.1)\end{array} \quad(1.1) \\
\mathrm{R}_{t-1}+0.006 \text { time }\end{array}$ \\
\hline (c)Oat & $\begin{array}{l}y_{t}=-15,2+0.31 y_{t-1}+0.008 \text { time }+0.32 D_{84} \cdot y_{t-1}+-0.0004 D_{84} \cdot \text { time }+e_{t} \\
\begin{array}{lll}(-4.5)(2.5) & (4.8)\end{array} \\
\mathrm{R}^{2}=0.91\end{array}$ \\
\hline (d)Maize & $\begin{aligned} y_{t}= & -11,8+0,81 y_{t-1}+0.006 \text { time }+e_{t} \\
& (-3.2)(13.8)\end{aligned}$ \\
\hline (e)Rice & $\begin{array}{l}y_{t}=-14,5+0.64 y_{t-1}+0.008 \text { time }-0.93 D_{50} \cdot y_{t-1}+-0.001 D_{50} \cdot t i m e+0.52 D_{80} \cdot y_{t-1}+-0.0008 D_{80} \cdot \text { time }+e_{t} \\
\begin{array}{llll}(-2.9)(2.2) & (3.2) & (-3.2) & (2.9)\end{array} \\
\mathrm{R}^{2}=0.78\end{array}$ \\
\hline
\end{tabular}

The Chow test identified a high probability of a break in rice yield growth in 1950. The model selection criterion clearly identified two breaks in the series, one in 1950 and one in 1980. The first break was associated with the period of decreasing yields and the second may have been associated with the same phenomenon previously described for wheat, barley and oat yields. The long-term relative rate of rice yield growth $\left(\beta_{2}\right)$ was $0.8 \%$ before 1950 and $0.9 \%$ afterward, but the rate was lower after 1980 (Table 2), meaning that it has always been positive and similar in magnitude to the rates of yield growth for the other cereals, although a period of negative yield did occur. It is important to note that estimates of long-term growth rates are based on the entire period, which explains the positive rates along the series. The period of negative growth in rice yield (before 1950) is explained by the AR(1) component, which changes over time. In the first period, the trend is negative; therefore, the AR(1) coefficient $\beta_{1}$ can be interpreted as a decrease in yield, which translates into another reduction in the future. During the second period, the coefficient $\beta_{1}$ of the past yield offsets the one in the second period, and in the third period it is positive, which is similar to what was observed for wheat, oat and barley. The goodness of fit of the model was greater than $75 \%$ (Table 2).

\section{Maize}

Maize is cultivated for grain production in the central valley of Chile, in a Mediterranean type of climate and with irrigation. Most of the land and soils for maize is shared with vineyards and various fruit tree species, and therefore the cropping area of maize is in strong competition with other profitable crops.

Although the trend in maize yield progress is similar to those of the cereals previously discussed, the components of this series differ in terms of trends. The yield progress of maize was very low before the sixties, the ten-year average having been below $2 \mathrm{t} \mathrm{ha}^{-1}$, but after the sixties, it increased steadily, reaching an average of 10.8 $\mathrm{t} \mathrm{ha}^{-1}$ in the past decade (Figure $3 \mathrm{~b}$, Table 1). The maize yield growth has fluctuated, having being negative in the thirties and forties, positive in the fifties and sixties and almost nil in the seventies and increasing substantially during the eighties (Table 1). The planted area also increased between the thirties and the nineties (Table 1).

Despite the changes that have occurred in the history of maize production in Chile, the Chow test did not indicate that any structural break occurred in the yield growth trend (Figure 2). 


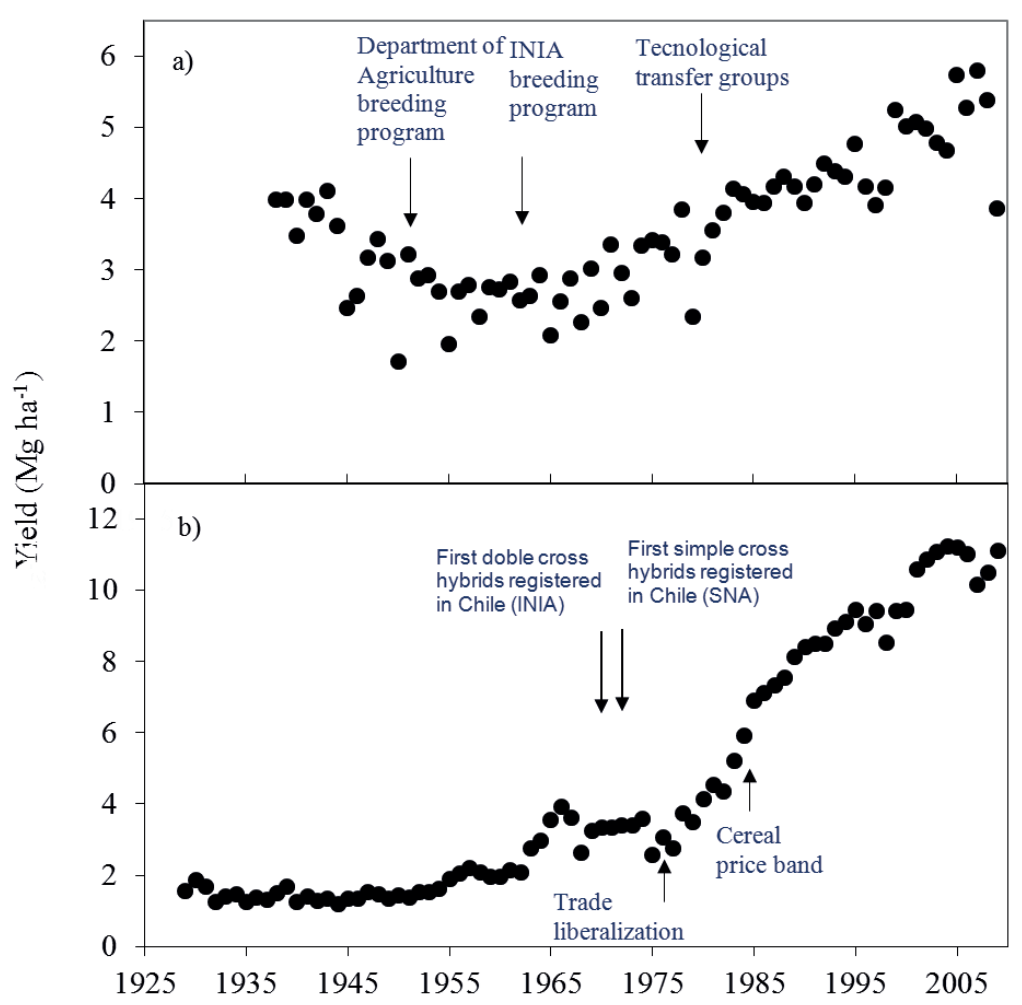

Figure 3. Average grain yields of rice (a) and maize (b) in Chile from 1927 to 2009, Specific events are marked with arrows.

According to the model, the long-term relative rate of yield growth was $0.6 \%\left(\beta_{2}\right)$. In addition to the long-term growth, the model estimate for short-term adjustment was $0.81\left(\beta_{1}\right)$, meaning that $81 \%$ of the past yield increases, on average, have translated into subsequent yield changes (Table 2). This could mean that maize growers have always adapted technology rapidly to their needs. The model has an $\mathrm{R}^{2}$ of 0.98 , and as before, the assumptions of linear regression models hold (Table 2).

\section{Discussion}

Cereal yield and technological improvement in Chile in the last century

Similar yield progress has been observed for wheat, barley, oat and rice in Chile, suggesting that common factors or events have influenced the country's average yield of these four cereals. The breakpoint in the eighties identified in the yield progress of these cereals is consistent with the break in the yield progress of wheat detected by Calderini and Slafer (1998).

A number of relevant events can be identified along the yield series (Figures 1 and 3). Although research in cereal breeding and crop management in Chile started early in the last century, it was not until the eighties that the average yield increased considerably. In the 1930s, the Ministry of Agriculture created the Departamento de Genética y Fitogenética, with twelve research stations distributed throughout the predominant agricultural regions in Chile. The Departamento de Investigación Agrícola del Ministerio de Agricultura was established in the forties. This was a precursor of the Instituto de Investigaciones Agropecuarias (INIA), founded in 1964 (Mellado, 2007), whose plant breeding programs for wheat, 
barley, oat and rice have played a significant role in the commercial varieties of these cereals used by Chilean farmers ever since.

Over 200 wheat cultivars have been developed in Chile during the 20th century. More than 50\% of these cultivars were available before 1980 (Mellado, 2007). Most of the spring cultivars released in Chile by INIA after the seventies were derived from material introduced by the Centro Internacional de Mejoramiento de Maíz y Trigo (CIMMYT). The genetic yield gains reported by Mellado (2007) were 18 and $24 \mathrm{~kg} \mathrm{ha}^{-1} \mathrm{yr}^{-1}$ for spring and winter cultivars, respectively, for the period 1968-1993. However, other studies of spring wheat have shown that the genetic gain over a longer period of time (1920-2005) had two phases, one before the sixties, with almost no gain, and a second after 1960, during which the genetic gain averaged $61 \mathrm{~kg} \mathrm{ha}^{-1} \mathrm{yr}^{-1}$ (Reyes, 2009). In the UK, the genetic gain has also been $61 \mathrm{~kg} \mathrm{ha}^{-1} \mathrm{yr}^{-1}$ over the last 20 years (Fischer and Edmeades, 2010). However, a lower genetic gain $\left(23 \mathrm{~kg} \mathrm{ha}^{-1} \mathrm{yr}^{-1}\right)$ has been reported for spring wheat grown in Mexico under irrigated conditions over the last 30 years (Fischer and Edmeades, 2010). Additionally, the genetic gain for wheat has been reported to have ranged between 32 and $72 \mathrm{~kg}$ $\mathrm{ha}^{-1} \mathrm{yr}^{-1}$ in three provinces in China for cultivars released between the sixties and the nineties (Zhou et al., 2007).

Similarly, the genetic gain of two-row barley in Germany for the period 1968-2003 was $39 \mathrm{~kg}$ ha $^{-1} \mathrm{yr}^{-1}$ (Ahlemeyer et al., 2005), and the genetic gain for oat in Italy for the period 1969-2004 was $36 \mathrm{~kg} \mathrm{ha}^{-1} \mathrm{yr}^{-1}$ (Redaelli et al., 2008). The genetic gain of wheat and barley after the sixties is mainly attributed to modifications of agronomic traits, such as reduction in plant size and increases in the harvest index and the number of grains per unit area (Abeledo et al., 2002; Fischer, 2007; Foulkes et al., 2007).

Our results show that wheat yield growth in Chile after the breakpoint (1983) was, on average, 101 $\mathrm{kg} \mathrm{ha}^{-1} \mathrm{yr}^{-1}$ (Table 1), whereas between 1960 and 1983, it was $13 \mathrm{~kg} \mathrm{ha}^{-1} \mathrm{yr}^{-1}$. It is also interesting to note that the breakpoint for genetic gain of wheat occurred about ten years before the break in the national average yield (Matus et al., 2012). This suggests that plant improvement contributed partially to yield progress and that other factors, such as appropriate agricultural public policies and economic incentives were factors in the adoption of technologies and agronomic management practices.

Rice has been cultivated since the thirties in clay soils in the central valley of Chile. Fertile soils not used before for cropping were incorporated as irrigation became available. As a consequence, during the first few decades of rice cultivation in Chile, no fertilization or weed control was used. The decline detected in productivity $\left(\beta_{I}\right)$ might have been the result of soil fertility depletion and weed competition. New genetic resources were introduced in the country when the first breeding program started in 1953 as a combined effort of the Departamento de Investigación Agrícola and private interests at the Estación Experimental Huencuecho in Pelarco, in the province of Talca in the Maule region of Chile. Breeding programs were created by INIA and continue to this day. Private companies, such as Indus in the 1970s, have also been involved in rice breeding.

A difference between rice and the cereals wheat, oat and barley is that few varieties of rice were able to fulfill the requirements of the growers and the industry (Alvarado, 2007). Today, rice farmers in Chile mainly use two old varieties, Diamante-INIA and Brillante-INIA, introduced by INIA in 1982 and 1997, respectively (Alvarado and Pino, 1982; Alvarado et al., 1997), and two modern varieties, Ambar-INIA (Alvarado and Hernaiz, 2005) and Zafiro-INIA (Cordero, 2011), introduced in 2005 and 2010, respectively. Because rice is cultivated in Chile at extreme latitudes and in a Mediterranean type of climate, one of the main focuses of INIA's rice breeding program is to develop highyielding cultivars with augmented tolerance to 
low temperatures during crop establishment and panicle development (Cordero, 2011). The yield potential of the new cultivars is over $12 \mathrm{t} \mathrm{ha}^{-1}$ (Alvarado, 2007), which is approximately 2.4 times greater than the national average yield in the last decade (5.0 t ha-1. Table 1$)$. In addition, good farmers are producing approximately $8 \mathrm{th}^{-1}$ of paddy rice. Although the farming conditions and cultivar availability for rice have been different from those of other cereals, mostly in terms of the concentration of a few varieties, the break point for rice yield increase in the eighties was similar to that for wheat, oat, and barley.

In maize, there have been large differences between the yield progress in Chile and that in North America. While in Chile, maize yields of 4 tha ${ }^{-1}$ were not achieved before the eighties, such yields were achieved in the sixties in the USA and Canada (Lee and Tolleran, 2007). However, the average maize yields in Chile and in North America since 2005 have been similar. The maize yield progress in the USA has been closely related to the development and use of hybrid types: first, double crosses used from the thirties to the fifties and then, single crosses used since the sixties (Crow, 1968). Before the sixties, only open-pollinated cultivars of maize were used in Chile. INIA first recorded the use of a double-cross hybrid in Chile in 1967, and the first single-cross (from the Sociedad Nacional de Agricultura, SNA) was registered in 1969 (according to records obtained from the Servicio Agrícola Ganadero, SAG). In the past 20 years, maize technology in Chile has been mostly imported because breeding programs have been associated with large private multinational corporations, according to SAG seed registration records (SAG, unpublished information).

The grain yield per hybrid in Iowa, USA, has increased linearly during the hybrid era (1930$2000 \mathrm{~s}$ ), and the genetic gain has been $79-116 \mathrm{~kg}$ $\mathrm{ha}^{-1} \mathrm{yr}^{-1}$ (Duvick, 2005; Fischer and Edmeades, 2010). According to Duvick (2005), 50\% of the grain yield progress in the USA has been due to plant breeding and $50 \%$ has been due to improved management practices. The genetic gain of maize has been a consequence of the modification of various physiological and agronomic traits, such as leaf angle (increase in leaf erectness), "stay green", changes in root and canopy architecture, increases in dry matter accumulation, reductions in tassel size and increases in the number of kernels per plant and per $\mathrm{m}^{2}$ (Duvick, 2005; Lee and Tolleran, 2007; Hammer et al., 2009; Fischer and Edmeades, 2010).

Long-term trends in yield and short-term innovation rates in productivity growth

The results of this study show that there has been a long-term trend in cereal yield growth in Chile, along with short-term innovations. The behavior of both components changed in the eighties for all crops except maize. This finding is interesting because despite genetic and management improvements of wheat, barley, oat and rice, they have undergone different evolutions, although the structural breaks in their yield growth trends occurred at similar times.

The long-term trend in the yield growth rates for wheat, barley, oat and rice decreased slightly after the eighties, as also been described in other case studies by Slafer and Kernich (1996) and Cassman (2003). Moreover, the percentage of relative yield growth ( $\beta_{2}$ in equations of Table 2$)$ was similar in all crops (i.e., approximately 0.6 to $1 \%$ ), diminishing after 1983/84 to almost the same degree for all of these crops. However, the estimated yield growth $\left(\mathrm{kg} \mathrm{ha}^{-1}\right.$ year $\left.^{-1}\right)$ for all cereals increased dramatically after the eighties (Table 1). There are two possible explanations for this. The first is that the relative rate decreased slightly and therefore the impact on absolute yield growth became more significant as yield increased. The second is that the AR(1) coefficient $\left(\beta_{1}\right)$ in the model, which represents the short-run yield adjustment, became higher after the eighties, leading to more rapid increases in yield. The $\beta_{1}$ coefficient can be interpreted as the 
learning and adoption capacity within the cereal production sector.

Maize has exhibited a different pattern, with no structural break identified in its yield growth rate trend (Figure 2). The substantial increase in maize yield in Chile during the eighties (Table 1) and the constant relative rate in yield increase estimated by the model can be explained by the progressive replacement of open-pollinated cultivars with hybrids and the rapid adoption of these hybrids. The yield potential of the new hybrids (mostly single cross) is very high, and good farmers are producing over $20 \mathrm{t} \mathrm{ha}^{-1}$ of maize in the central valley of Chile. Therefore, it is expected that the maize yield will continue to increase in the coming decades, as it has since the eighties.

What factors other than genetic improvement have contributed to cereal yield progress in Chile? Our results suggest that the change in the short-run adjustment could be the consequence of more competitive behavior as a result of economic liberalization and more access to improved technologies. The liberalization of trade policy could have affected the rate of technological improvements in two ways: (i) technology became more available and affordable for producers as import tariffs decreased (from an average of 35\% in 1984 to 11\% in 1991; Agosin and French-Davis, 1994), contributing to an increase in yield rates; and (ii) as the country opened its borders to the world, businesses needed to become more competitive and therefore poorly performing cereal producers were edged out. Moreover, since the beginning of the eighties, the agrarian sector has benefited from the implementation of public policies that were nonexistent during the seventies, such as the implementation of price bands to reduce the variability of price fluctuations, the implementation of Comercializadora de Trigo S.A. (COTRISA) as a market power to stabilize the domestic price of wheat, and later the implementation of an irrigation policy that subsidized small-scale investment to promote more efficient irrigation techniques (Errázuriz and Muchnik, 1996). This process was accompanied by an intensive outreach program, implemented in 1982 by INIA and INDAP, oriented toward producers of any size. The outreach program has been positively evaluated in terms of its encouragement of adoption of technology and reductions in production costs (Portilla, 2000).

Another factor that could also help to explain the break in yield trends after 1983 is the evolution of the real exchange rate. Although cereal prices were declining internationally, domestic prices did not decrease at the same rate because the real exchange rate increased after the economic crisis of 1982 (Errázuriz and Muchnik, 1996), generating incentives to adopt technologies. Considering all of the factors discussed above, we infer that a combination of appropriate agricultural policies and economic incentives are essential to the innovation process; therefore, the availability of technology to farmers is not in itself sufficient for its implementation.

\section{Acknowledgements}

The authors are very grateful to Dr. José Luis Araus (Universidad of Barcelona) for his useful comments on the manuscript. 


\title{
Resumen
}

\begin{abstract}
A. Engler y A. del Pozo. 2013. Evaluación de las tendencias de corto y largo plazo en rendimiento de cereales: caso de Chile entre 1929-2009. Cien. Inv. Agr. 40(1):55-67. La producción de cereales de grano ha aumentado en todo el mundo durante el siglo 20, como consecuencia del mejoramiento genético de plantas, mejores prácticas de manejo y el uso intensivo de insumos. Sin embargo, hay evidencia de que existen diferencias en la evolución de los rendimientos entre países y especies de cereales. El objetivo de este artículo fue comparar las tendencias en los rendimientos de los cereales más importantes en Chile, es decir, trigo, avena, cebada, maíz y arroz,identificar las similitudes en las tendencias de los distintos cultivos y estimar las tasas de crecimiento de largo plazo de los rendimientos y los cambios en tiempo. Los datos correspondientes a trigo, cebada, avena, arroz y maíz entre 1929 y 2009 se obtuvieron de la Oficina Chilena de Estudios y Políticas Agrarias (ODEPA). El modelo de autorregresión de primer orden (AR1) fue utilizado para las series temporales de rendimiento de grano por hectárea, con el fin de estimar las tasas relativas de incremento de la producción y los ajustes de corto plazo en el progreso del rendimiento. Se encontró un quiebre en las series temporales para el trigo, la cebada y la avena en torno a 1980. Después de esto, los rendimientos mostraron fuertes incrementos, alcanzando los tres cereales rendimientos similares (4.4-4.7 $\mathrm{t} \mathrm{ha}^{-1}$ en la última década). La tasa relativa a largo plazo de rendimiento fue de aproximadamente $0.6-1 \%$ antes del quiebre (alrededor de 1980) y luego disminuyó ligeramente. La producción de arroz disminuyó de los años treinta a los años sesenta y luego se incrementó hasta el presente. En el maíz, el rendimiento fue muy bajo antes de los años sesenta $\left(<2 \mathrm{t} \mathrm{ha}^{-1}\right)$, pero aumentó en forma constante hasta el presente, alcanzando un promedio de 10,8 $\mathrm{t} \mathrm{ha}^{-1}$ en la última década. Los cambios económicos que se producen en el país pueden explicar los quiebres que se observan en las tendencias de los cereales.
\end{abstract}

Palabras clave: Arroz, avena, cebada, maíz, progreso de rendimiento, trigo.

\section{References}

Agosin, M., and R. Ffrench-Davis. 1994. Liberalización comercial y desarrollo en América Latina. Nueva Sociedad 133:57-71.

Abeledo, L.G., D.F. Calderini, and G.A. Slafer. 2002. Genetic improvement of barley yield potential and its physiological determinants in Argentina (1944-1998). Euphytica 130: 325-334.

Ahlemeyer, J., F. Aykut, W. Köhler, W. Friedt, and F. Ordon. 2005. Genetic gain and genetic diversity in German winter barley cultivars. Options Méditerrnnéenes, Series A, N²1: 43-47.

Alvarado, R., and A. Pino. 1982. Arroz Diamante INIA. Agricultura Técnica (Chile) 42: 253.

Alvarado, R. 2007. Arroz: Manejo Tecnológico. Instituto de Investigaciones Agropecuarias, Chillán, Chile. Boletín INIA Nº2. 180 pp.
Alvarado, R., and S. Hernaiz. 2005. Ambar-INIA, nuevo cultivar de arroz de grano corto y muy bajo contenido de amilosa. Agricultura Técnica (Chile) 65:101-104.

Alvarado, R., S. Hernaiz, A. Gómez, and F. Saavedra. 1997. Brillante INIA, nueva variedad de arroz con grano largo y translúcido. Agricultura Técnica (Chile) 57:221-222.

Calderini, D.F., and G.A. Slafer. 1998. Changes in yield and yield stability in wheat during the 20th Century. Field Crops Research 57:335-347.

Cassman, K., A. Dobermann, D. Walters, and H. Yang. 2003. Meeting cereal demand while protecting natural resources and improving environmental quality. Anual Review of Environmental Research 28:315-358.

Chloupek, O., P. Hrstkova, and P. Schweigert. 2004. Yield and its stability, crop diversity, adaptability 
and response to climate change, weather and fertilisation over 75 years in the Czech Republic in comparison to some European countries. Field Crops Research 85:167-190.

Cordero, C. 2011. Mejoramiento genético de arroz en Chile: una estrategia país en la seguridad alimentaria nacional. Tierra Adentro 96:49-51.

Crown, J.F. 1998. 90 years ago: the beginning of hybrid maize. Genetics 148:923-928.

Dadi, L., M. Burton, and A. Ozanne. 2004. Duration analysis of technological adoption in Ethiopian agriculture. Journal of Agricultural Economics 55: 613-631.

Duvick, D.N. 2005. The contribution of breeding to yield advances in maize (Zea mays L.). Advances in Agronomy 86: 83-145.

Edwards, S. 1985. Stabilization with liberalization: An evaluation of ten years of Chile's experiments with free-market policies 1973-1983. Economic Development and Cultural Change 33: 223-254.

Enders, W. 1995. Applied Econometric Time Series. Wiley Series in Probability and Mathematical Statistics. John Wiley \& Sons Inc. USA. 433 pp.

Egli, D.B. 2008. Comparison of corn and soybean yields in the United States: historical trends and future prospects. Agronomy Journal 100: S-79-S-88.

Errázuriz, L.F and E. Muchnik. 1996. Visión Crítica de la Agricultura Chilena y sus Políticas. Estudios Públicos 61. Centros de Estudios Públicos (CEP). $48 \mathrm{pp}$.

Evans, L.T. 1993. Crop evolution, Adaptation and Yield. Cambridge University Press. p. 500.

Evenson, R., and D. Gollin. 2003. Assessing the impact of the Green Revolution, 1960 - 2000. Science 300:758-762.

Fischer, R.A. 2007. Understanding the physiological basis of yield potential in wheat. Journal of Agriculture Science 145:99-113.

Fischer, R.A., and G.O. Edmeades. 2010. Breeding and cereal yield progress. Crop Science 50:S-85-S-98.

Foulkes, M.J., J.W. Snape, V.J. Shearman, M.P. Reynolds, O. Gaju, and R. Sylvester-Bradley. 2007. Genetic progress in yield potential in wheat: recent advances and future prospects. Journal of Agricultural Science 145:17-29.
Grant, K. 1997. Trends in Atlantic Canada`s potato industry. Canadian Journal of Agriculture Economic 45:439-450.

Greene, W.H. 2008. Econometric Analysis (6th edition). Prentice Hall. Upper Saddle River, NJ, USA. 1178 pp.

Halloran, J.M., and D.W. Archer. 2008. External economic drivers and US agricultural production systems. Renewable Agriculture and Food Systems 23:296-303.

Hammer, G.L., Z. Dong, G. McLean, A. Doherty, C. Messina, J. Schussler, C. Zinselmeier, S. Paszkiewicz, and M. Cooper. 2009. Can changes in canopy and/or root system architecture explain historical maize yield trends in the U.S. Corn Belt? Crop Science 49:299-312.

Latiri, K., J.P. Lhommeb, M. Annabia, and T.L. Setterc. 2010. Wheat production in Tunisia: Progress, inter-annual variability and relation to rainfall. European Journal of Agronomy 33:33-42.

Lee, E.A., and M. Tollenaar. 2007. Physiological basis of successful breeding strategies for maize. Crop Science 47:S-202-S-215.

Lobell, D., and C. Field. 2007. Global scale climatecrop yield relationships and the impacts of recent warming. Environmental Research Letters 2:1-7.

Lütkepohl, H. 2005. A New Introduction to Multiple Time Series Analysis. Springler- Verlag. Berlin, Germany. 324 pp.

Matus, I., Mellado, M., Pinares, M., Madariaga, R., and del Pozo, A. 2012. Genetic progress in winter wheat cultivars released in Chile from 1920 and 2000. Chilean Journal of Agricultural Research 72:303-308.

Mellado, M., 1999. Mejoramiento de trigos harineros (Triticum aestivum L.) en la zona Centro Sur de Chile. 1. Análisis del rendimiento y variables asociadas en variedades de invierno y facultativas. Agricultura Técnica (Chile) 59:283-295.

Mellado, M. 2000. Mejoramiento de trigos harineros (Triticum aestivum L.) en la zona centro sur de chile. II. Análisis del rendimiento y variables asociadas en trigos de primavera. Agricultura Técnica (Chile) 60:32-42.

Mellado, M. 2007. El Trigo en Chile. Instituto de Investigaciones Agropecuarias, Centro Regional 
de Investigación Quilamapu. Colección Libros INIA N ${ }^{\circ} 21$. Chillán, Chile. 684 pp.

Milberg P., and E. Hallgren. 2004. Yield loss due to weeds in cereals and its large-scale variability in Sweden. Field Crops Research 86:199-209.

Portilla, B. 2000. La política agrícola en Chile: lecciones de tres décadas. Comisión Económica para America Latina y el Caribe (CEPAL). Serie de documentos $N^{\circ}$ 68. Santiago, Chile. 64 pp.

Redaelli, R., P. Laganà, F. Rizza, O. Li Destri Nicosia, and Cattivelli, L. 2008. Genetic progress of oats in Italy. Euphytica 164:679-687.

Reyes, J.M. 2009. Estudio del avance genético de genotipos de trigo harinero primaveral sembrados en Chile con distinto año de liberación. Memoria de Título Ingeniero Agrónomo. Universidad de Talca. Talca, Chile. 36 pp.

Slafer, G., and G. Kernich. 1996. Have changes in yield (1900-1992) been accompanied by a decrease yield stability in Australia cereal production? Australian Journal of Agriculture Research 47:323-334.

Zhou, Y., Z.H. He, X.M. Chen, D.S. Wang, J. Yan, X.C. Xia, and Y. Zhang. 2007. Genetic improvement of wheat yield potential in North China. In: Buck, H.T., J.E. Nisi, N. Salomón (eds.). Wheat Production in Stressed Environments, SpringerVerlag, New York Inc, USA. p. 583-589. 
